\title{
Airborne LiDAR prospection at Lovea, an Iron Age moated settlement in central Cambodia
}

\author{
Dougald O’Reilly ${ }^{1, *}$, Damian Evans ${ }^{2} \&$ Louise Shewan $^{3}$
}

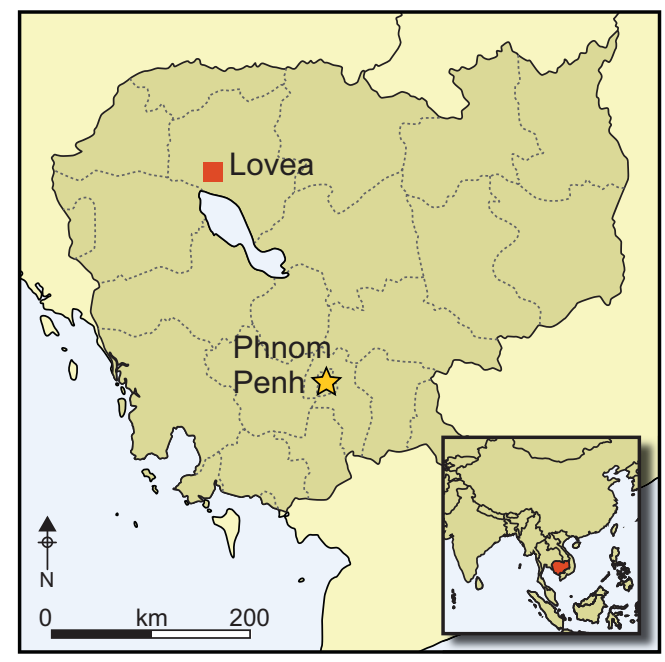

These strategies grew in complexity, culminating in the vast network of canals, reservoirs and tanks that are the hallmarks of the hydraulic society of Angkor.

Keywords: Cambodia, Lovea, Iron Age, LiDAR, water management

Recent archaeological investigations and technological applications have increased our appreciation of the intricacies of preAngkorian societal development. The results reveal a transformative period characterised by increasing socio-political complexity, exchange and technological transfer, differences in burial wealth, growing levels of conflict and variation in site morphology. Among the excavated Iron Age sites in Cambodia, Lovea, near the heart of Angkor, is well placed to provide a greater understanding of these changes in this region. Excavation and remote sensing confirm that the two moats surrounding Lovea are testimony to the early adoption of water-management strategies.
in the vast network of canals, reservoirs and

\section{Introduction}

The archaeological site of Lovea (Figure 1) is one of only a few known moated sites in Cambodia, and it is the only one to have been excavated. Here, two substantial earthen embankments are separated by moats surrounding the occupation mound (Figure 2). While the inner embankment is rather fragmented, the outer embankment is better preserved but not entirely intact. Lovea is morphologically similar to other moated archaeological sites found in north-east Thailand, and was specifically selected for excavation to provide comparative data for these sites, particularly Non Ban Jak, which was excavated

\footnotetext{
The Australian National University, School of Archaeology and Anthropology, Canberra, ACT 2601, Australia École française d'Extrême-Orient, Boeung Daun Pa, Slorkram, Siem Reap, Cambodia

3 The University of Melbourne, School of Earth Sciences, Melbourne, VIC 3010, Australia

* Author for correspondence (Email: dougald.oreilly@anu.edu.au)
} 


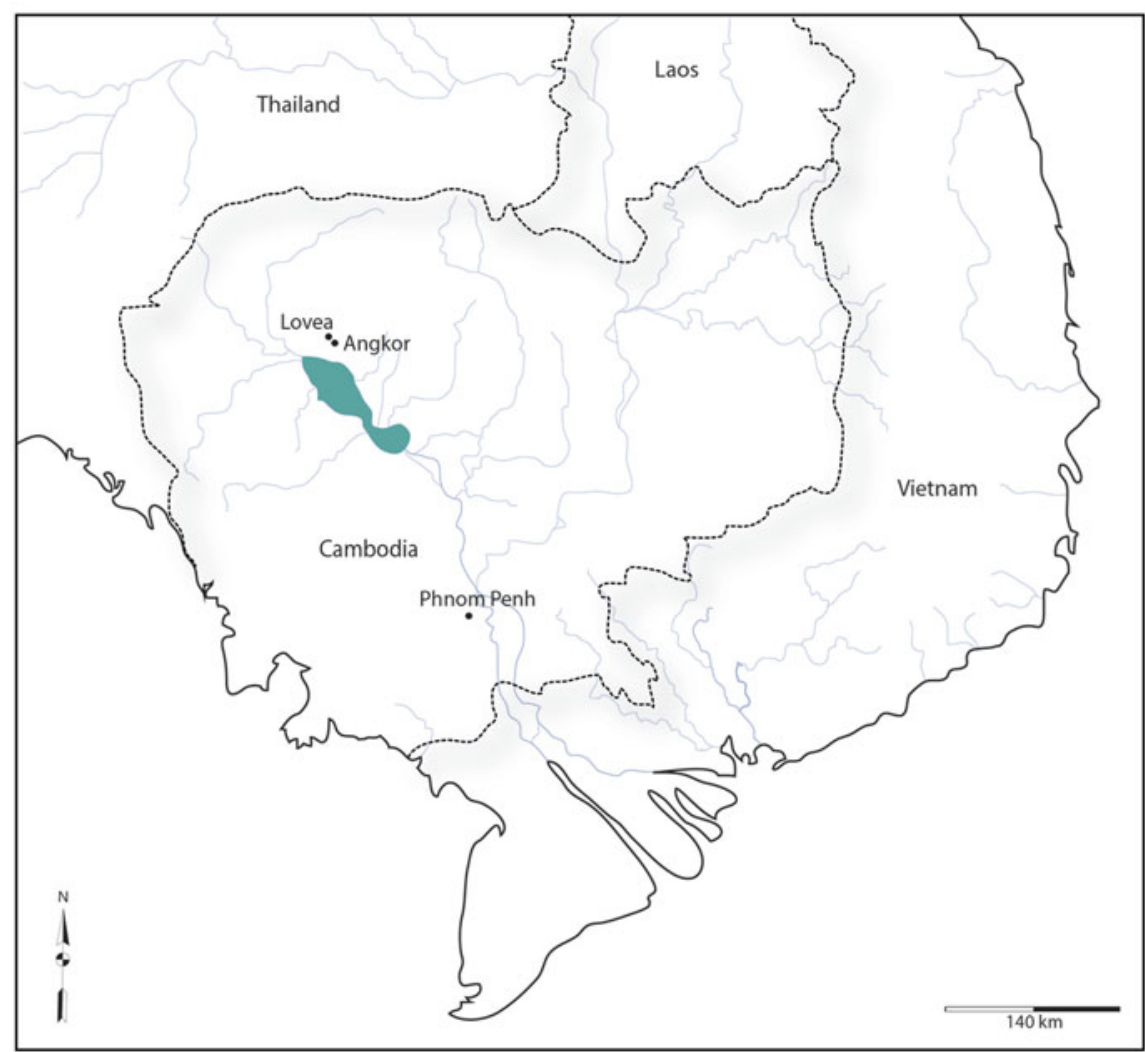

Figure 1. Map of Cambodia showing the location of Lovea.

concurrently (Higham et al. 2014). As part of the archaeological investigations at Lovea (O'Reilly \& Shewan 2015), targeted areas of the embankments and their associated moats were excavated and mapped using traditional archaeological survey and high-precision airborne laser scanning (LiDAR). These data suggest that these anthropogenic features were designed for the purposes of water management.

Lovea is located in Puok District, Siem Reap Province at $13^{\circ} 29^{\prime} 04.4^{\prime \prime} \mathrm{N}$ and $103^{\circ}$ $42^{\prime} 47.0^{\prime \prime} \mathrm{E}$ (Figure 1). Lovea has been of archaeological interest since the 1950s, when Louis Malleret (1959) of the École française d'Extrême-Orient recorded the existence of two embankments enclosing the village. At present, a village occupies a low mound measuring $210 \mathrm{~m}$ north-south and $312 \mathrm{~m}$ east-west. Investigation of the site and its surroundings was conducted to examine the emergence of complex Southeast Asian societies prior to the rise of the Angkorian state. Two excavation seasons were conducted between 2011 and 2013. The investigation comprised the excavation of two units on the mound, revealing twelve mortuary contexts with associated grave goods, and six excavation units on the two embankments. Lovea appears to be a multi-period site spanning several distinct periods, perhaps continuously, from the prehistoric era until the present day.

(C) Antiquity Publications Ltd, 2017 

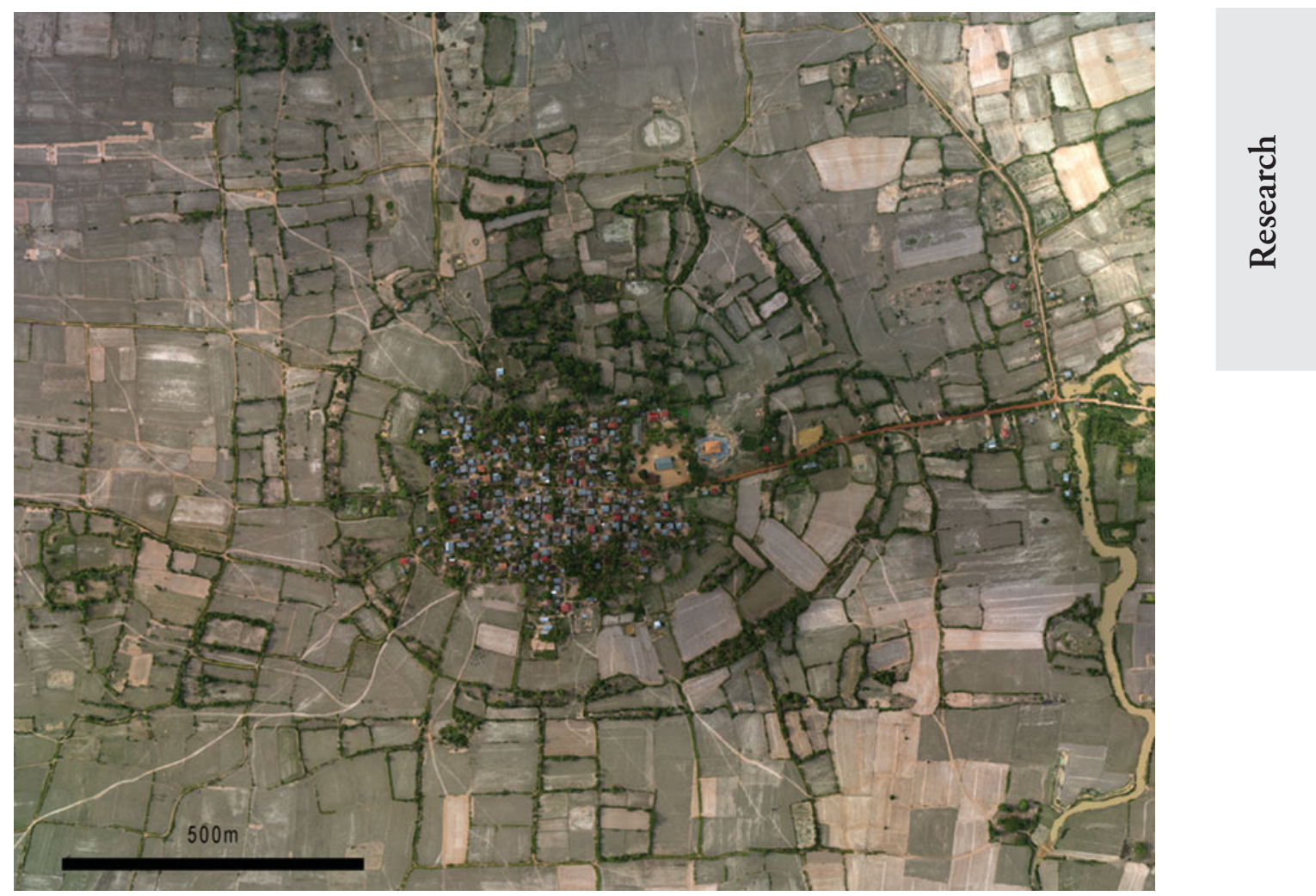

Figure 2. An orthophotograph mosaic of Lovea and its environs, derived from aerial photography acquired during the 2012 LiDAR campaign.

\section{Methods}

\section{Archaeological methodology}

Excavations were undertaken on the mound of Lovea (units 1-2) and on the embankments surrounding the site (units 3-7) (Figure 3). Unit 1, an $8 \times 8 \mathrm{~m}$ trench, revealed evidence of Iron Age occupation (including the mortuary assemblages of 12 individuals) and apparent continued occupation since then. This data is detailed in a recent publication (O'Reilly \& Shewan 2015).

Unit 2, located on the occupation mound, was excavated in arbitrary $100 \mathrm{~mm}$ spits to investigate prehistoric habitation and mortuary contexts. Units 3-7 were excavated to investigate the morphology of the moats and embankments, and to ascertain their possible function. Targeted areas on the embankments were excavated using arbitrary spits with efforts made to recognise stratigraphic layers that differed in colour. The layer number is cited first, followed by the spit number (e.g. layer 1 , spit 1 is denoted as 1:1). Where archaeological features were encountered, a distinct, consecutive feature number is provided for these (e.g. layer 1:1, feature one is recorded as 1:1 F1). The locations and dimensions 


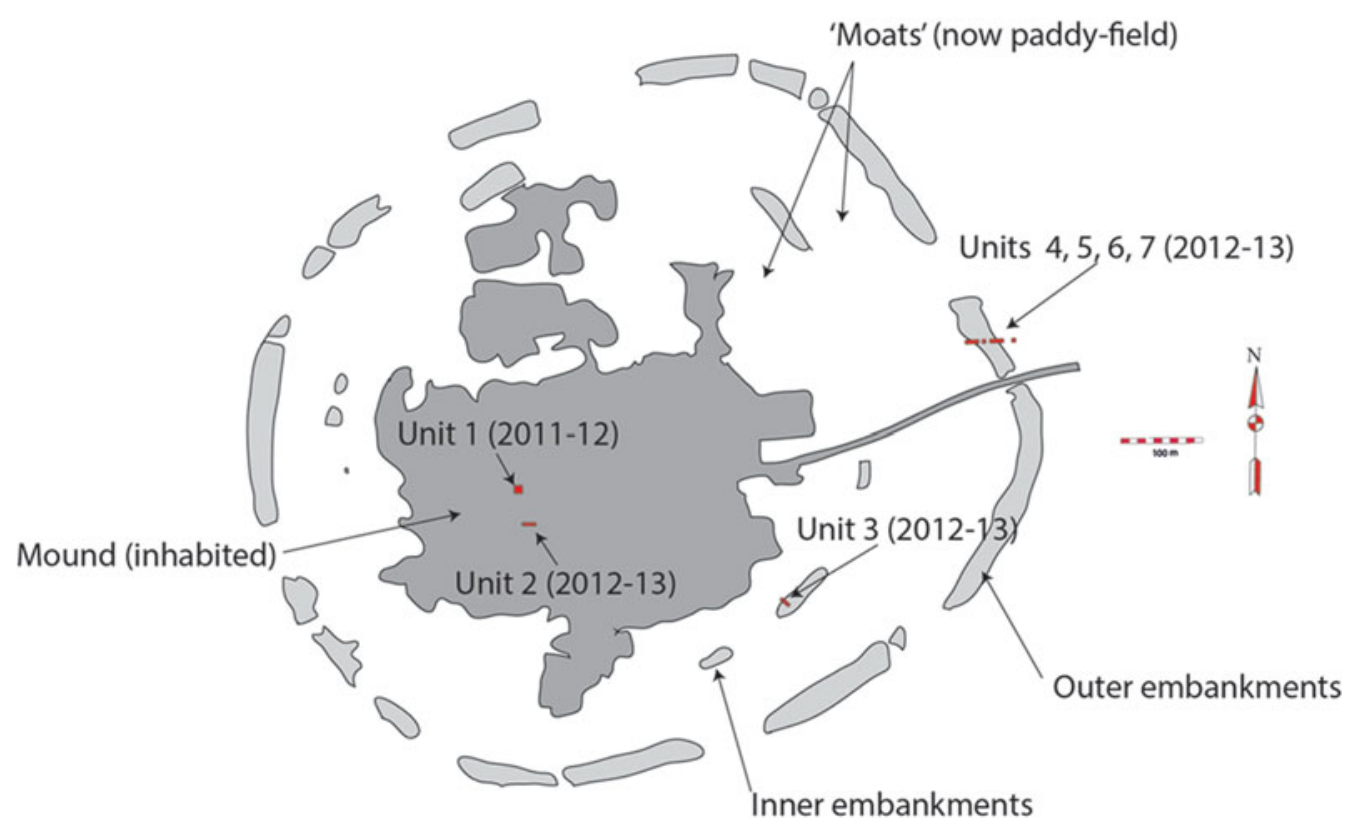

Figure 3. Map of Lovea indicating the location of the units of excavation.

of the units excavated during 2012-2013 are detailed in the online supplementary material (Table S1).

\section{LiDAR methodology}

In March 2012, a 370 km² LiDAR survey was completed by the Khmer Archaeology LiDAR Consortium (KALC) to create a high-resolution, high-precision elevation record of central Angkor and other areas of archaeological significance in north-west Cambodia (Figure 4) (Evans et al. 2013). This included the village of Lovea and its surroundings, comprising a $2.35 \mathrm{~km}^{2}$ block. LiDAR uses a laser beam that is transmitted from a device carried in a plane or helicopter. During flight, laser beams are transmitted to the ground and are reflected back to the device. The time taken to cover the distance there and back is used to calculate the distance between flying platform and the surface. These distance measurements are used to create a three-dimensional map, both of the landscape's archaeological topography and of the vegetation that normally obscures it from conventional sensors. To obtain the accuracy required for mapping archaeological sites, a satellite location system, such as GPS, is required, as well as very precise flight paths, surveyed ground control points and instrumentation to account for the altitude and attitude of the aircraft.

LiDAR acquisition methodology employed at Lovea was generally the same as that already described in detail by Evans et al. (2013), with some key differences. A Leica ALS60 laser system and 40 megapixel Leica RCD105 medium-format camera (with a $60 \mathrm{~mm}$ lens) were installed within an external pod mounted to a Eurocopter AS350 B2 helicopter. The instrumentation included a Honeywell CUS6 Inertial Measurement Unit, which registered aircraft orientation at $200 \mathrm{~Hz}$. Absolute positional information was acquired by a Novatel (C) Antiquity Publications Ltd, 2017 


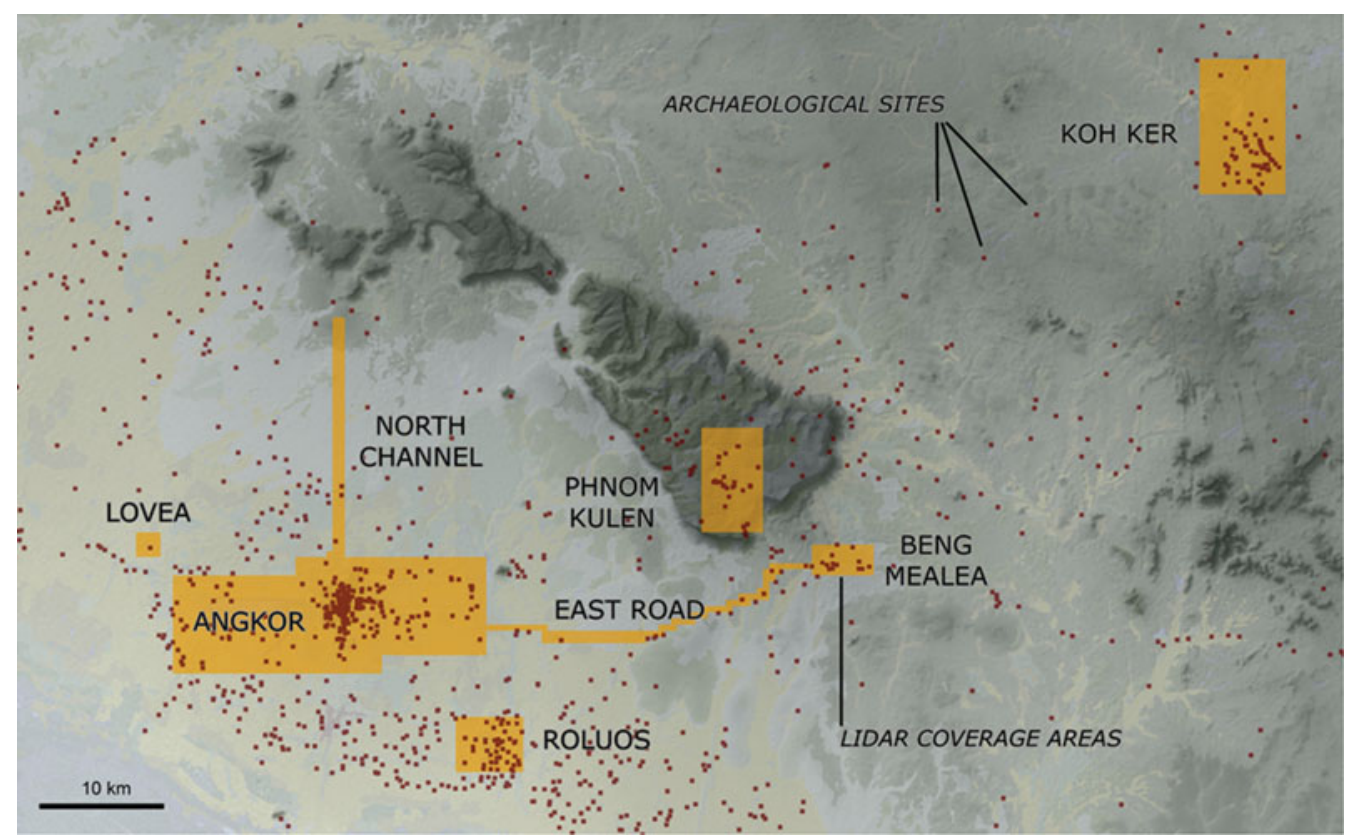

Figure 4. KALC LiDAR acquisition areas in north-west Cambodia. Archaeological sites courtesy of the Ministry of Culture and Fine Arts, Cambodia; background topographic data courtesy of JICA and NASA-SRTM.

L1/L2 GPS antenna attached to the tail rotor and logging positions at $2 \mathrm{~Hz}$. The flight plan was designed with cross-hatch pattern over moderate to heavily vegetated areas to maximise ground returns; flights over open areas, including at Lovea (Figure 5), were in a single direction (east-west in this case). Flight lines were flown in opposing directions to ensure that overlapping data could be analysed for laser alignment; the single-pass LiDAR swath width averaged $650 \mathrm{~m}$ with 50 per cent sidelap. A flying height of $800 \mathrm{~m}$ above ground level and a speed of 80 knots were chosen to give the optimal point densities, providing a field of view of $45^{\circ}$ for the laser scanner and a default of $46^{\circ}$ for the camera. The ALS60 was set at a pulse rate of $105 \mathrm{kHz}$ in regular (single-pulse-in-air) mode with four returns recorded per pulse; full waveform data were not acquired at Lovea. Single-pass LiDAR point densities averaged 2-3 points per $\mathrm{m}^{2}$ and raw photo images were collected at $80 \mathrm{~mm}$ resolution.

Position measurements from the aircraft-mounted GPS were post-processed using differential correction data from Trimble R8 GNSS base station receivers installed at surveyed benchmarks, at a distance of no more than $\sim 25 \mathrm{~km}$ from any acquisition point in the Lovea block, and logging positional information at $1 \mathrm{~Hz}$. Prior to the mission, test points were established at two test sites for calibration using an RTK GPS with $\sim 100$ points per site; both of these calibration sites were overflown on the (single) aircraft sortie in which data for Lovea were captured. Project specifications for accuracy were a root-mean-square error (RMSE) of within $150 \mathrm{~mm}$ compared to surveyed ground control points. All survey measurements were based on the master benchmark for the area, and all data were collected and processed in the WGS84 datum using ellipsoid heights. 


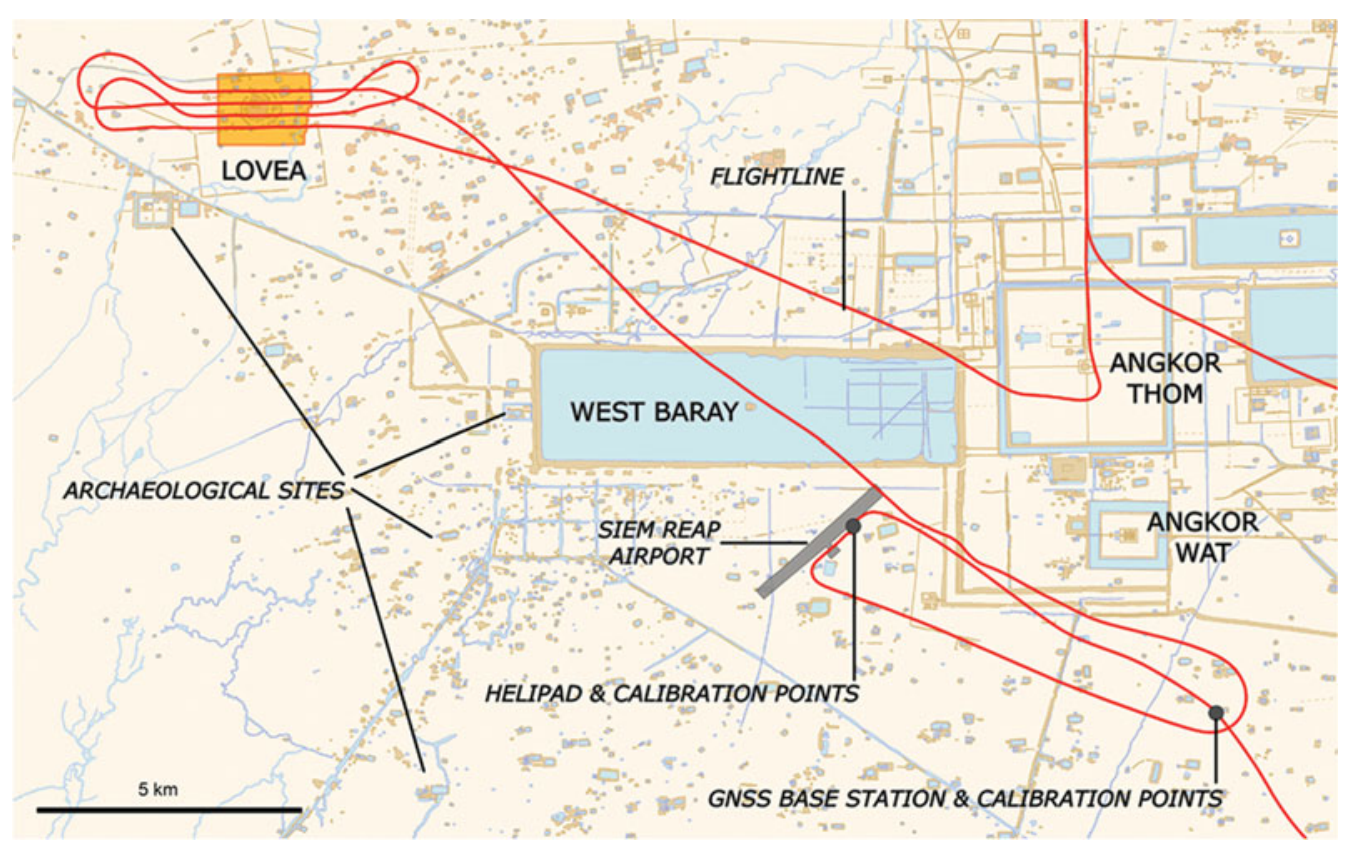

Figure 5. Flight lines and supporting ground elements for the 2012 LiDAR acquisition over Lovea. Background archaeological data from Evans (2007).

Raw laser data were processed against the ground survey data to ensure data quality and conformance with project tolerances for spatial accuracy and precision. The raw data points were then imported into the Terrascan software environment and processed by McElhanney Indonesia, PT, using a proprietary ground point identification algorithm. This process divided the data into two separate datasets consisting of 'ground' and 'non-ground' returns. Outputs were hand-checked by editors, and manually cross-referenced against georeferenced aerial photograph data (Evans et al. 2013). The 'ground' measurements were then post-processed into digital terrain models, hillshade models and local relief models in an ArcGIS software environment (Figure 6), manually analysed and interpreted, and loaded into hand-held GPS units for systematic field verification of newly identified features within the Lovea acquisition block.

\section{Results}

\section{Unit 2 excavation}

Four layers were identified during the excavation of unit 2, the first comprising items of modern material culture in stratified light-coloured sand. Below this layer, the soil gradually turned to dark grey and contained Angkorian sherds. A third, light-orange layer was uncovered, containing one mortuary context. This comprised the poorly preserved cranium and mandible of a young adult, of unknown sex. Below the third layer was a hard, dark, compacted layer representing the natural substrate, approximately $1.7 \mathrm{~m}$ below the ground surface.

(C) Antiquity Publications Ltd, 2017 


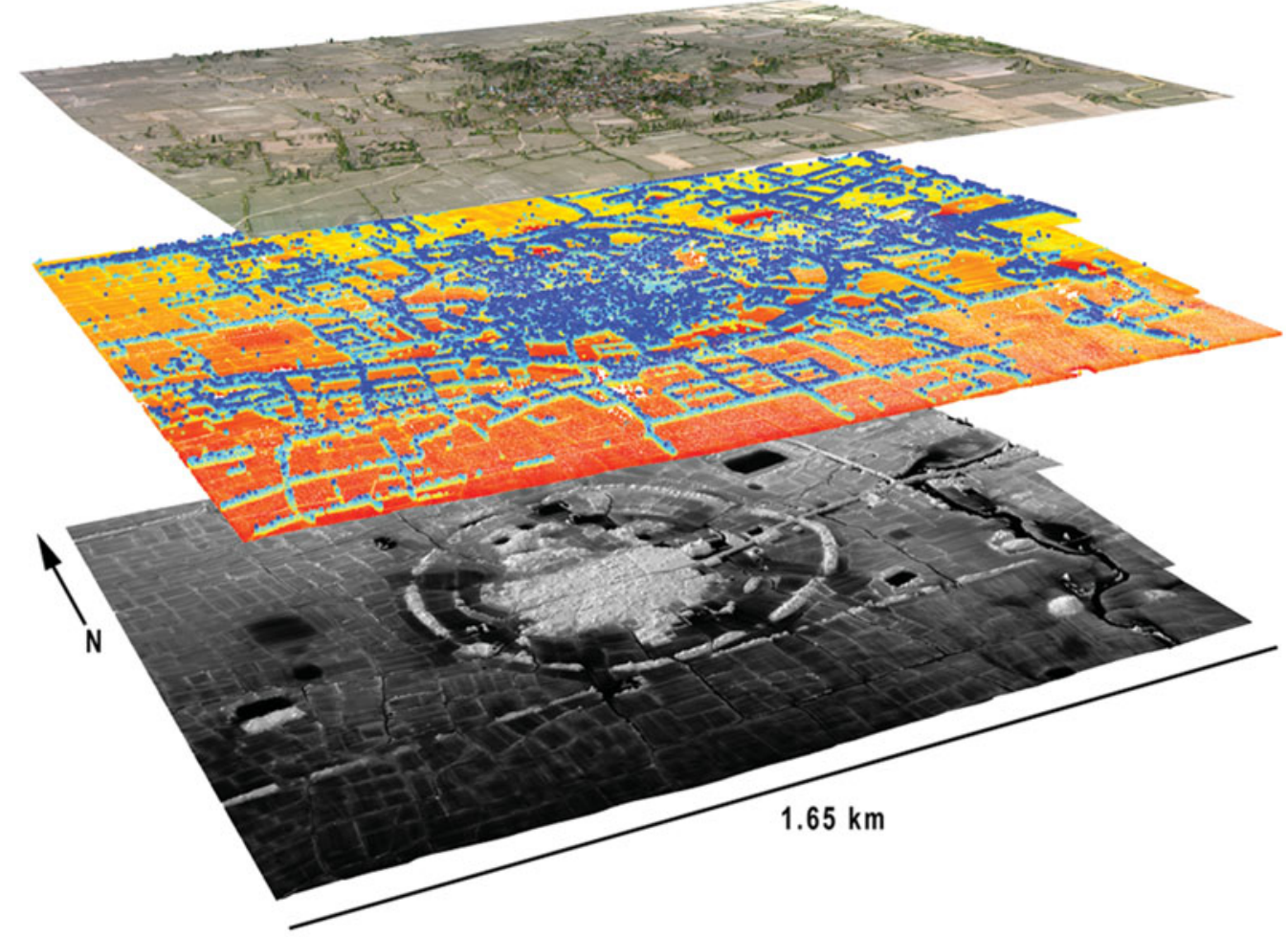

Figure 6. Top: composite aerial photography from the KALC acquisition, with elevation from the non-ground LiDAR data. Centre: representation of non-ground LiDAR point cloud with $5 \times$ vertical exaggeration on a red (lowest points) to blue (highest points) scale. Bottom: digital terrain model derived from LiDAR ground returns and merged with a hillshade model, $5 \times$ vertical exaggeration.

\section{Unit 3 excavation (inner embankment)}

Three layers were identified in unit 3. The first layer yielded a small number of glazed stoneware and porcelains sherds. Layer 2, comprising a reddish-yellow matrix, yielded stoneware pottery sherds and glazed stoneware indicative of the Angkor period. An earthenware ceramic vessel was discovered in the north baulk. Layer 3 comprised a pinkishgrey soil devoid of any cultural material. The water table was met at about $0.9 \mathrm{~m}$ below the surface. From the natural substrate to the top of the embankment the difference in elevation was $1.2 \mathrm{~m}$. Unit 3 presented solid stratigraphic evidence for human agency in the creation of the inner embankment that encircles the site. The stratigraphic profile of unit 3 is represented in Figure 7. It appears that stratum (E) was cut to create the inner moat. The situation is complicated, in that stratum (D), as expected, also appears to have been cut but continues into the moat. This perhaps occurred as a result of erosion of the embankment. Stratum (G) may represent sedimentation of the moat, stratum (F) a later erosion event, and strata (C) and (B) represent natural soil accumulation. Stratum (A), within the moat, represents soil recently disturbed by agricultural activity. 
A 7.5 YR $3 / 2$ e 7.5 YR $5 / 6$

8 5 YR $4 / 1 \quad 07.5 Y R 5 / 4$

$8.5 Y R 5 / 2$ a $7.5 Y R 6 / 4$
0

e 7.5 YR $6 / 2$
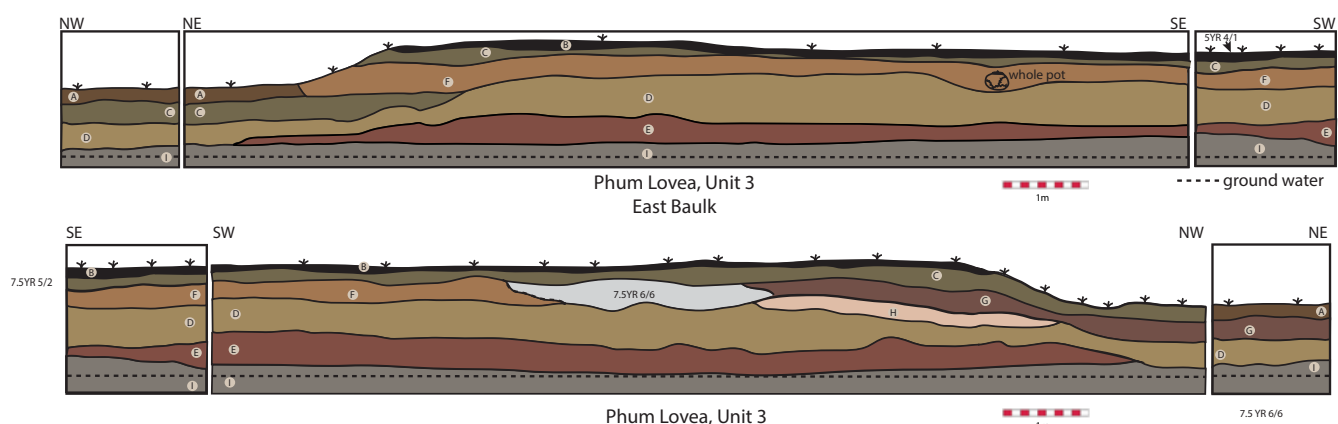

West Baulk
Mum Lovea, Unit

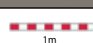

$7.5 \times 6 / 6$

Figure 7. Illustration indicating the stratigraphic profile of unit 3 at Lovea. 


\section{Unit 4 excavation (outer embankment)}

The stratigraphy of unit 4 is represented in Figure 8. The first layer yielded two brownglazed stoneware sherds and a sherd identified as Qingbai (greenish-white) glazed stoneware. The matrix in this layer was varied. In layer 2 the soil colour varied across the unit, with no visible features aside from a very shallow circular feature (around $80 \mathrm{~mm}$ deep). Layer 3 , a natural, pinkish-grey deposit, contained no artefacts or features. As in unit 3, there was clear evidence of human manipulation of the matrix. In section, it is apparent that the eastern end of the unit had been disturbed by prehistoric excavation. The section is complex, but it appears that stratum (D) on the south baulk (see Figure 8) was cut by the excavation of the moat. Stratum (E) may represent in-fill through sedimentation, and the overlying strata (B) and (C) may represent erosion from the embankment. There is also evidence for infilling to the east end of the embankment. This is probably the result of run-off and the subsequent development of an 'A horizon' (stratum (A)), which was disturbed by recent agricultural activity.

\section{Unit 5 excavation (outer embankment)}

Unit 5 comprised a 9m-long trench across the embankment, with a further $3 \mathrm{~m}$ extending into the rice field to the west. Layer 1 produced several earthenware sherds, an earthenware roof tile sherd and charcoal. Reddish-yellow layer 2 yielded charcoal fragments and earthenware sherds. Layer 3 comprised a yellowish-red natural substrate, devoid of evidence for human alteration. There was minimal difference in elevation between the moat and the top of the embankment in unit 5 . This was possibly due to moat in-filling as a result of embankment erosion, or deposition of sediment during moat use. In unit 5, on the western side of the outer embankment, there is a similar stratigraphic complexity at the edge leading into the moat (Figure 9). Evidence of moat excavation is apparent (stratum (D) is cut). It appears that the moat was in-filled, probably naturally, by stratum (B), and the moats fell out of use. Some modification of the top of the embankment is apparent (perhaps levelling) following the in-filling of the moats (represented by stratum (C)). The uppermost stratigraphic layer, the A horizon (A), represents natural soil deposition.

\section{Unit 6 excavation (outer embankment)}

Layer 1 of unit 6 was grey in colour. Layer 2, a pinkish-grey matrix $0.6 \mathrm{~m}$ below the surface, was only $100 \mathrm{~mm}$ thick. Here, the soil became softer and wetter due to the presence of ground water. Light-brown layer 3 (Figure 9) represented the natural or sterile layer upon which the embankment was built. Excavation was stopped at a depth of $1.8 \mathrm{~m}$. The matrix at this depth was speckled with ferrous inclusions, and the soil was stained with rust spots (probably from lateritic soil). Unit 6 yielded no artefacts, nor was any evidence of a palisade uncovered in the form of postholes.

\section{Unit 7 excavation (outer embankment)}

Unit 7 was excavated in the low-lying paddy field to determine if there had been a prehistoric river bed in this location. The unit, measuring $2 \mathrm{~m}$ long and $1.5 \mathrm{~m}$ wide, was 


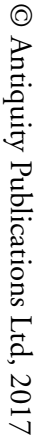

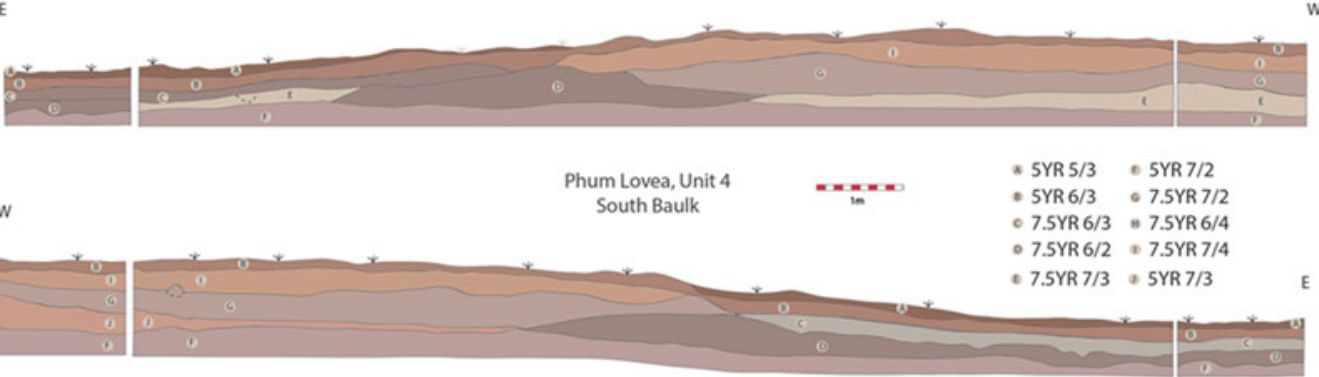

Phum Lovea, Unit 4

$+\infty$

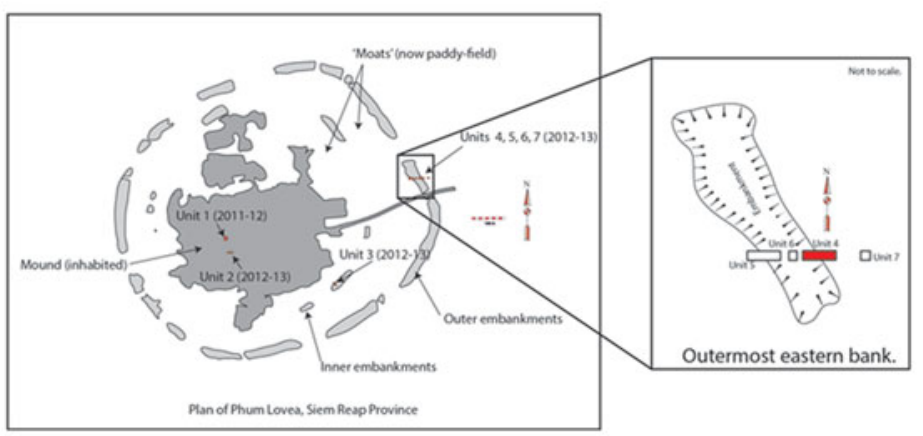

Figure 8. Illustration indicating the stratigraphic profile of unit 4 at Lovea. 
Phum Lovea, Unit 5

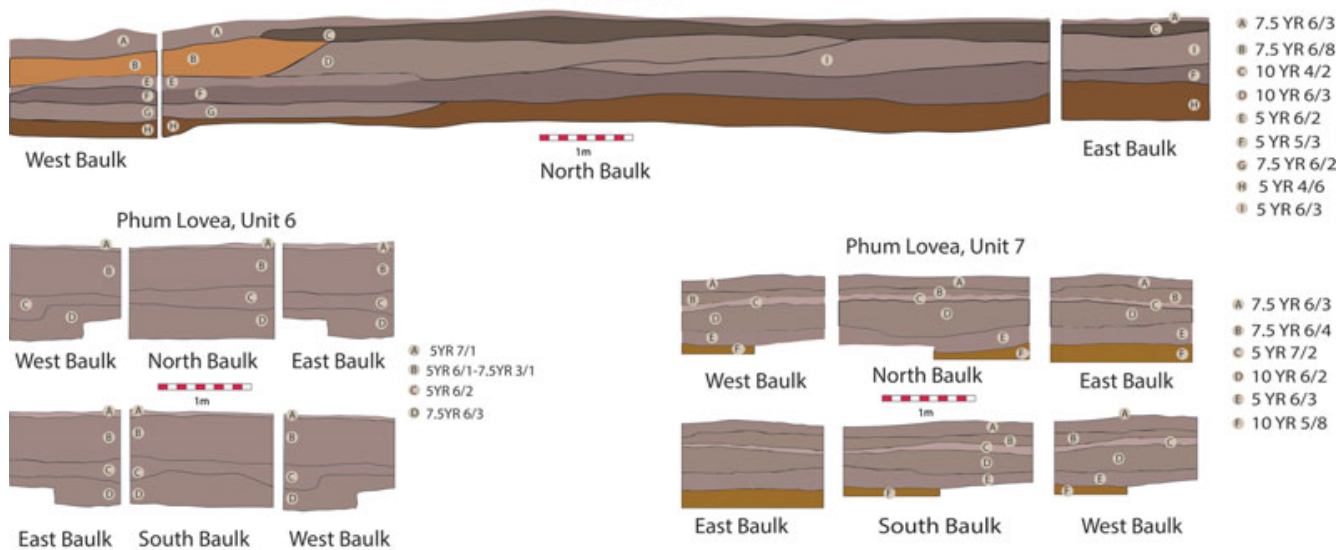

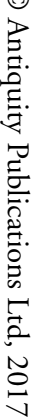

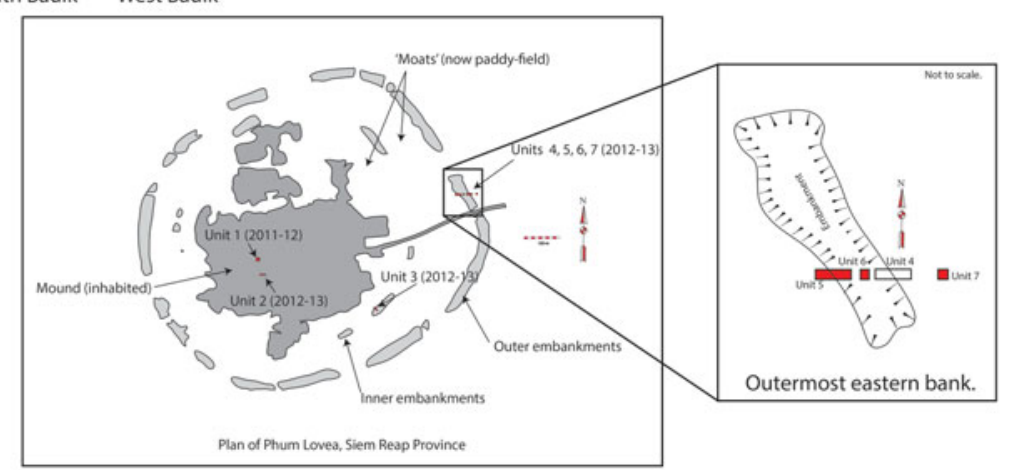

Figure 9. Illustration indicating the stratigraphic profile of units 5-7 at Lovea. 
located $12 \mathrm{~m}$ to the east of unit 4 . Unit 7 was excavated to a depth of $0.9 \mathrm{~m}$. The matrix was not sieved for cultural material, as the purpose of the excavation was to assess the nature of the stratigraphy. Six stratigraphic layers were identified that varied in colour from light brown to yellowish brown. The matrix of the sterile lowest layer was speckled with ferrous inclusions, as was the case in unit 6. There is no evidence of fluvial activity in unit 7 (Figure 9).

\section{LiDAR results}

The total coverage area of the block was approximately $2.35 \mathrm{~km}^{2}$. Within this area, 10512846 individual measurements were acquired, for an average point density of 4.47 points per $\mathrm{m}^{2}$. After post-processing, this dataset was further divided into 4473294 nonground and 6039552 ground points, for an average of 1.9 points and 2.57 points per $\mathrm{m}^{2}$, respectively. In addition to laser-scanning data, conventional aerial photographs were also acquired.

\section{Discussion}

\section{Archaeological data: units 3-7}

The outer embankment that encircles Lovea, although substantial, is less well stratigraphically defined than the inner embankment (see unit 3, above). Excavation of unit 3 indicates that the natural soil was excavated in prehistory to create the inner moat at Lovea. It appears that the embankment created by excavation of the moat later eroded, with earth being deposited back into the moat. Evidence of sedimentation within the moat indicates that it was, at one time, filled with water. The area of the moat has been, and continues to be, used for agricultural purposes.

In unit 4, on the east side of the outer embankment, evidence suggests that the sterile substrate was dug into in the past; the more complex nature of the stratigraphy atop the embankment suggests that soil was manually deposited to form the embankment. The excavation of unit 4 revealed strong evidence for excavation of the moat and its later sedimentation due to erosion of the associated embankments.

Unit 5 revealed little elevational difference between the embankment and the moat. This was probably due to erosion of the embankment and subsequent in-filling of the moat through sedimentation and run-off. Again, on the western side of the unit, there is evidence for the original excavation of the moat and its later in-filling.

Unit 6, located in the middle of the outer embankment, was excavated to investigate evidence for a palisade having been located here. Much of the matrix represents redeposited soil above a natural, sterile layer. No artefacts were recovered from unit 6, nor was any evidence for a palisade uncovered.

Unit 7 was excavated to investigate the existence of a prehistoric river near the eastern side of the site, which may have served to fill the moats. Excavation, however, yielded no evidence of fluvial deposits.

The excavation of units 4-7, the profiles of which can be seen in Figures 8 and 9, suggest that the moat and embankments were anthropogenic in nature and most probably constructed for the purpose of water retention. The area within the embankment is lower (C) Antiquity Publications Ltd, 2017 
than that outside, enabling water storage. Charcoal samples were deemed unsuitable for radiometric dating.

\section{LiDAR data}

Morphological analysis of the mound complex was conducted in an ArcGIS environment using LiDAR data, in association with high-resolution satellite data and conventional aerial photographic prints (Figure 10). The post-processed digital terrain model revealed the structure of the terrain without any obfuscation from vegetation cover, and with minimal interference from the relatively dense urban development on top of the prehistoric mound.

The site of Lovea is located at the point where the alluvial fan merges into the floodplain of the Tonle Sap, and is in an area of almost no significant natural topographic relief (Kummu 2009). The LiDAR data confirm previous interpretations of the site as an irregularly shaped but roughly circular mound, distinctly larger than the typical occupation mounds of the 'classic' Angkor period (Pottier 1999; Evans 2007). Taken as an assemblage, the main central mound and the small surrounding occupation mounds exhibit similar morphology to several dozen other prehistoric sites documented in the Angkor region since the work of Moore (1985), and that have been mapped in detail by Pottier (1999) and Evans (2007), and subsequently analysed by Hawken (2011). Hawken conducted a topographic examination of Cambodian prehistoric sites, and suggests that the prehistoric landscape comprises settlement mounds with ox-cart tracks and rice fields radiating from them. According to Hawken (2011), these tracks functioned to integrate the settlement into clusters, thereby suggesting contemporaneity. The remnant moats and circular enclosures are unambiguous at Lovea and, in this respect, and based on recent mapping work (Hawken 2011), the site is highly anomalous among the prehistoric mounded sites of north-west Cambodia, where such features are exceptionally rare.

As with most other prehistoric mounded sites in the region, the Lovea complex is somewhat fragmented and has been heavily modified by natural processes and through re-use and re-occupation in subsequent centuries. It is difficult, therefore, to reconstruct the precise 'original' morphology of the mound from surface data alone. Nonetheless, some preliminary assessments can be made. Firstly, we can unequivocally confirm the existence of an outer embankment encircling the site, with a depression on its inner side that can be reasonably interpreted as a moat; if the interior depression were merely a borrow pit resulting from the construction of embankments, we would expect the depression to be limited to the immediate vicinity of the embankment. It appears, however, that care was taken to remove soil from a band of at least $30 \mathrm{~m}$ in width to create a broad depression that is much more characteristic of a moat than of a borrow pit. Furthermore, the authors identify narrow depressions at various points on the exterior of the outer embankment that can be interpreted as borrow-pits for the construction of that embankment (Figure 10), although the possibility that these borrow pits represent the remains of a heavily fragmented exterior moat must be considered.

Although Lovea is occasionally described as a multi-vallate site with at least two concentric ditches and embankments (e.g. Higham 2014: 830), it is difficult to discern the innermost embankment/ditch configuration precisely, even with the LiDAR data 

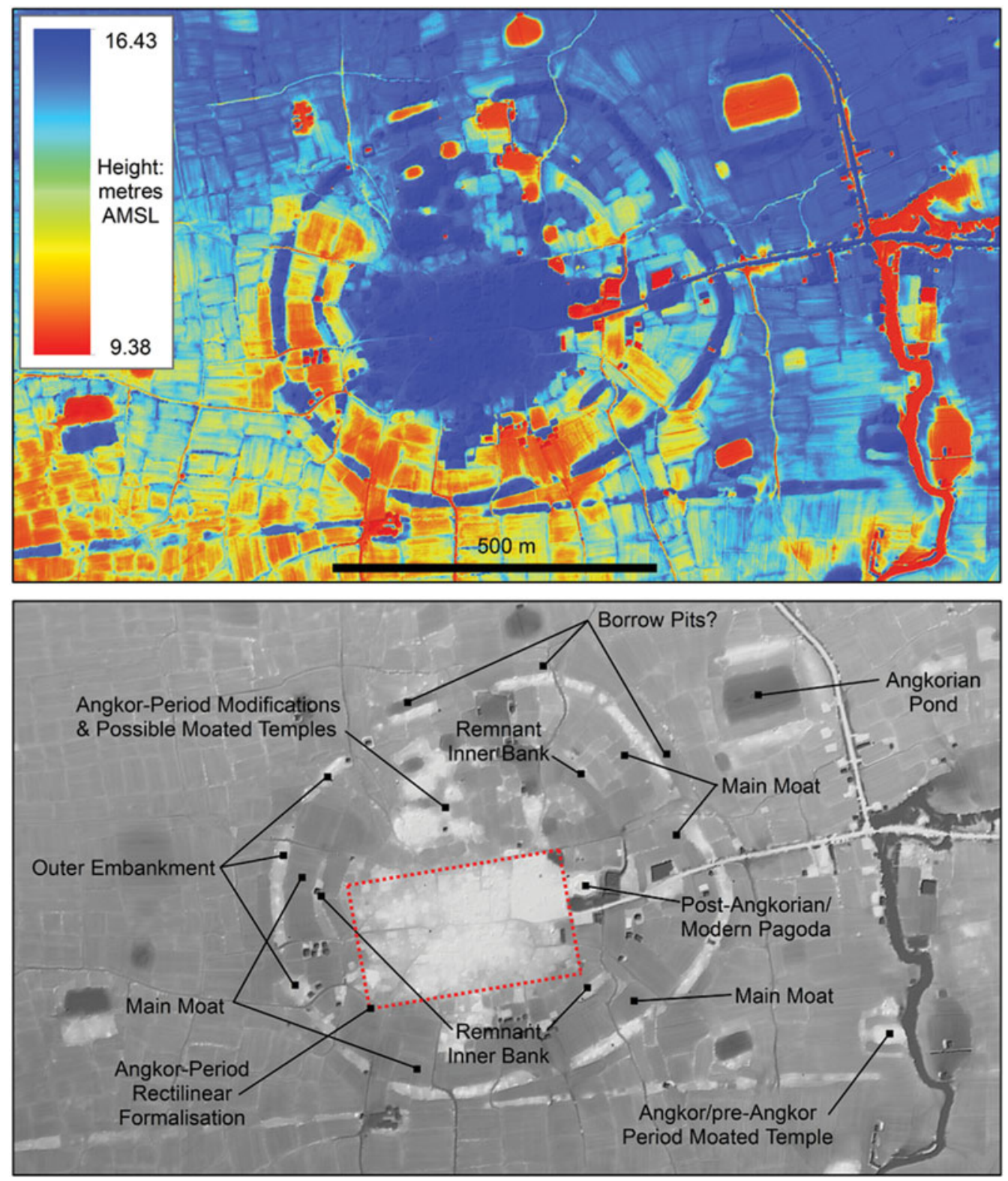

Figure 10. Top: digital terrain model derived from LiDAR ground returns, colour-coded according to elevation in metres above mean sea level. Bottom: annotated greyscale digital terrain model denoting features that are mentioned in the text and that are visible in the top image.

(Figure 10). A number of features are indicative of an interior embankment and ditch, particularly on the eastern and western sides. On the northern and southern sides, however, there are significant interruptions to this pattern, including the existence of mounds and ponds that would seem to preclude use of the moats and embankments for a defensive purpose.

(C) Antiquity Publications Ltd, 2017 
The LiDAR data also clearly identify 'radial features' described by Hawken (2011) and Pottier (1999, 2000). These features comprise patterns of ox-cart tracks and low field walls or bunds emanating outward from the central mound. Although this configuration is typical of prehistoric mounds in the Angkor area, further study should be devoted to the question of whether these are a reflection of the original (prehistoric) configuration of the landscape, or whether such patterns simply evolved as a matter of course around (essentially) circular sites with modern villages atop them. The excavations of Baty et al. (2005) at the Siem Reap Airport demonstrate that through constant renovation and repair by farmers, bunds can persist vertically through many stratigraphic layers. Hence, they remained fundamentally unchanged on the surface over at least a millennium, even if the original field walls are substantially buried beneath the ground.

The LiDAR data permit an investigation of the function of the outer 'moat'. The site covers an area that slopes gently from the north-east to the south-west. Mapping the height profile using the LiDAR data shows that Lovea covers an incline that reduces the overall landscape height from just over $12.5 \mathrm{~m}$ (AMSL) in the north-east to just under $12 \mathrm{~m}$ in the south-west (Figure 10). A similar height profile of the outer embankment of Lovea reveals that it remains at a consistent $13 \mathrm{~m}$ in height along its entire length, irrespective of the topography of the land upon which it is built (Figure 10). It is, therefore, less than $0.5 \mathrm{~m}$ above the surrounding landscape on the north-north-east side, but more than $1 \mathrm{~m}$ above the surrounding landscape on the southern side. As such, it is inconsistent with the expectation for either a defensive or elevated roadway function. The consistent absolute height for the top of the embankment suggests that the structure was designed for water storage.

As the depth of the moat follows the topography, the water within may have been significantly shallower in the north-east than in the south-west. Moats are subject to infill and are therefore significantly more difficult to interpret than extruded features, such as embankments, in the absence of excavation or coring. This suggests either that (a) the depth of the moat was not of primary importance to the builders; and/or (b) that they lacked the skills or technology required to measure and maintain a consistent water depth around the whole circumference. The height of the embankment would easily have been identified by prominence above the water level of the moat and maintaining a consistent height would have been of the utmost importance, otherwise the wall would have failed and the water drained.

Finally, interpretation of the structure and distribution of the mounds confirms the above-mentioned hypothesis that the mound complex was modified heavily during the pre-Angkorian and/or Angkorian periods. Aside from the existence of characteristically 'Angkorian' pond-and-mound configurations within the outer embankment of Lovea, there is reasonably clear evidence that the main central mound of the site had been formalised at a later stage into a rectangular shape, oriented to the north-east (Figure 10).

\section{Water management and socio-political development}

The importance of the findings at Lovea should not be underestimated, as they affect our understanding of the trajectory of socio-political development not only in Cambodia, but also regionally. The implications could also have significance in global archaeology. The 
hypothesis that the moats around archaeological sites were employed for water storage was recently advanced by O'Reilly (2014). It is argued that the construction of moats around sites dating to the Iron Age in north-east Thailand represents a critical step in the evolution of hierarchical social systems beginning c. 400 BC (Higham 2014). O'Reilly (2014) sought to demonstrate that control of water may, at least in part, explain the development of hierarchies clearly identified in the region.

The construction of channels or moats around sites created a controllable resource: water. In a region of unpredictable rainfall and frequent drought, water contained in moats would have become a valuable resource that could be used to irrigate nearby rice fields in times of need. Critical to the argument that control of water contributed to the development of entrenched hierarchies is whether the water contained in the channels around these sites was sufficient for use in agricultural purposes. Analysis of a random sample of sites in north-east Thailand indicates that a significant majority (72 per cent) of the sampled sites had moats large enough to hold water that would irrigate enough land to produce emergency rations for the estimated populations of the sites (O'Reilly 2014).

This hypothesis has received support through recent analysis of the distribution of these sites in north-east Thailand and of rainfall patterns. It is clear that the majority (81.8 per cent) of moated sites are located in regions with the lowest precipitation on the Khorat Plateau (Scott \& O'Reilly 2015). Furthermore, it was found that the areas of lower precipitation hosted smaller sites compared to those in higher rainfall areas, and sites found in lower rainfall areas tended to have more moats around them (O'Reilly \& Scott 2015). The moats around these sites represent a possible catalyst for a tiered society, in which the emergent elite may have seen an opportunity to strengthen their power base and create a permanent hierarchical structure. As Higham (2014) has noted, profound changes are evident in north-east Thailand during the Iron Age, including the introduction of new and exotic valuables interred with the elite and the production of ploughshares and other agricultural tools. It is possible, given the evidence presented here, that a similar process was underway at Lovea.

The Iron Age in Thailand, as described by Higham (2014), has four phases. The first three of these are identified at Ban Non Wat, all four at Noen U-Loke and the last two phases at Non Muang Kao. The most recently excavated moated site in the region, Non Ban Jak, was only occupied during the final phase. The first phase of the Iron Age dates, according to Higham (2014), between c. 420 and 100 BC. It has been identified at Ban Non Wat, where the dead were interred with mortuary goods similar to those of the Bronze Age. Iron is found in many of the interments, and, rarely, also glass and semi-precious stone artefacts (Higham 2011). In terms of social differentiation, neither of the two groups of burials ascribed to this period, nor any individual, was distinguished in terms of prestigious grave offerings (Higham 2012). At Noen U-Loke only, six burials belonging to the first phase were identified. These contained iron weapons, ornaments and agricultural tools, but no stone or glass jewellery. One group in the cemetery was distinguished by the presence of torcs of bronze and iron, animal-canine pendants and shell ornaments (Higham et al. 2007).

The second phase of the Iron Age falls between c. 100 BC and AD 200 (Higham 2014), and is represented by two burial clusters at Noen U-Loke. The dead were placed in graves (C) Antiquity Publications Ltd, 2017 
filled with rice and young pigs, but rarely were ceramic vessels included. Curiously, no iron was found. Glass and semi-precious stone first appeared at Noen U-Loke during this period.

The third Iron Age phase falls between AD 200 and 400. At Noen U-Loke Higham et al. (2007) discovered four separate burial groups, in which differences in burial wealth were exhibited. Differential burial wealth is also observed in the late Iron Age phases of Ban Non Wat (Higham \& Higham 2009).

In the final phase of the Iron Age (AD 400-600) recognised at Noen U-Loke, Non Muang Kao, and Non Ban Jak, Higham (2014) notes that the dead were poorer than those in the preceding phase, at least in the area excavated. At Non Ban Jak, Higham has identified the disposal of the dead in residential contexts, which he notes may reflect rising social inequality (Higham pers. comm.). It is during the Iron Age 3-4 periods that the moats and embankments at the excavated sites were created (Higham 2014). He notes that former rivers were linked to the moats, in some instances; linear features, possibly representing water-capture and -distribution features, were also recorded (Higham 2014: 827). Dates obtained from Lovea suggest that the mortuary activity here dates to $c$. AD 130-345, or the equivalent of Iron Age 3 in north-east Thailand.

It has been suggested that the shift towards a hierarchical society may have occurred as a response to environmental variability (White 1995: 112). The Khorat Plateau of northeast Thailand has climate patterns of strong seasonality, with periods of extremely low precipitation and drought risk. All of this is broadly analogous to the local climate over the past 3000 years (cf. Kealhofer \& Penny 1998; White et al. 2004; Cook \& Jones 2012; Penny pers. comm.). Habberfield-Short and Boyd's (2007) analysis of palaeoenvironmental data in the Mun Valley identified six phases of change, with a significant decline in rainfall in the Iron Age 3 phase. The construction of these moats during Iron Age 3 and 4 would have necessitated considerable manpower; it may be argued that the organisation and control required to create these features may be attributed to the existence, or development of, hierarchical social systems. This, together with a concomitant increase in the number of agricultural tools and the inclusion of rice in burial contexts, may hint at an agricultural surplus (Higham 1998).

It has been proposed recently (O'Reilly 2014) that hierarchy became entrenched during the Iron Age in the Mun River Valley as individuals took control, first of access to water and later, into the historic period (post $\mathrm{AD} 500$ ), of land. It is possible that nascent Iron Age elites, as suggested by differential burial wealth at Ban Non Wat and Noen U-Loke, possessed the organisational capacity to undertake large-scale construction projects, such as the excavation of channels around habitation sites. Having control over water stored in the circular channels around the habitation sites would place the elite in a position of power over the population.

\section{Conclusion}

Lovea represents one of the few 'moated' sites identified in Cambodia, and the only such site to have undergone excavation and scientific analysis. Archaeological investigation of the occupation mound revealed an agrarian community whose occupants engaged in regional trade and exchange, and who buried their dead with a range of grave goods (O'Reilly 
\& Shewan 2015). The combination of remote-sensing techniques and archaeological investigation of the encircling embankments and moats at Lovea confirm that the features are anthropogenic and strongly suggest that they were constructed for the purpose of water retention. There is no evidence that the embankments at any time hosted occupation, or that they were designed for use as a defensive palisade. This landscape modification demonstrates the establishment of a rudimentary water-retaining strategy. It is argued that the organisation and control required to construct and maintain these features should be attributed to the development of hierarchical social systems. Such emergent watermanagement strategies soon transformed, with the establishment of the Angkorian state, into an exceptionally sophisticated and complex hydraulic engineering system.

\section{Acknowledgements}

The authors would gratefully like to acknowledge the participation and acquiescence of the people of Phum Lovea, the APSARA Authority, including H.E. Bun Narith, H.E. Ros Borath, H.E. Mao Laor and especially our close collaborators, H.E. Tan Boun Soy, Tin Tina, An Sopheap, Kim Samnang, Im Sokrithy, Ea Darith, Chhay Rachna and Tho Thon, who made an invaluable contribution to this effort, and to the Government of Cambodia for their generous support and cooperation. We also thank the Australian Research Council for funding the research through the Discovery Grants programme, and we gratefully acknowledge the LiDAR data obtained by the KALC team. Thanks also go to our colleagues in the field including Suy Pov, Siang Lim, Marc Veerhoven, Var Inariddh, Cherryln Wong, Kasper Hanus, Georgia Roberts, Nang Sy, Andrew Ball and to the volunteers. Thanks also to the staff of the Robert Christie Research Center for their support, especially So Malay. We thank PT McElhanney Indonesia for their contribution to the LiDAR acquisition, and acknowledge support and funding from eight institutions of the Khmer Archaeology LiDAR Consortium: the APSARA National Authority, the University of Sydney, the École française d'Extrême-Orient, Société Concessionaire d'Aéroport, the Hungarian Southeast Asian Research Institute, Japan-APSARA Safeguarding Angkor, the Archaeology and Development Foundation and the World Monuments Fund.

\section{Supplementary material}

To view supplementary material for this article, please visit https://doi.org/10.15184/aqy. 2017.69

\section{References}

BATY, P. 2005. Extension de l'aéroport de Siem Reap 2004. Rapport de fouille archéologique. Siem Reap: APSARA; Paris: INRAP.

Соoк, C. \& R. Jones. 2012. Palaeoclimate dynamics in continental Southeast Asia over the last $\sim 30,000$ cal yrs BP. Palaeogeography, Palaeoclimatology, Palaeoecology 339: 1-11. http://doi.org/10.1016/j.palaeo.2012.03.025

Evans, D. 2007. Putting Angkor on the map: a new survey of a Khmer 'Hydraulic City' in historical and theoretical context. Unpublished $\mathrm{PhD}$ dissertation, University of Sydney.
Evans, D., R. Fletcher, C. Pottier, J.-B. Chevance, D. Soutif, S.T. Boun, S. Im, D. EA, T. Tin, S. Kim, C. Cromarty, S. De Greef, K. Hanus, P. Baty, R. Kuszinger, I. Shimoda \&

G. Boornazian. 2013. Uncovering archaeological landscapes at Angkor using Lidar. Proceedings of the National Academy of Sciences of the USA 110: 12595-600.

http://doi.org/10.1073/pnas.1306539110

HabBerfield-Short, J. \& W. Boyd. 2007. The geoarchaeology of Noen U-Loke and Non Muang Kao, in C.F.W. Higham, A. Kijngam \& S. Talbot (ed.) The origins of the civilisation of Angkor. Volume two. The excavation of Noen U-Loke and Non Muang Kao: 29-53. Bangkok: Fine Arts Department.

(C) Antiquity Publications Ltd, 2017 
Hawken, S. 2011. Metropolis of ricefields: a topographic classification of a dispersed urban complex. Unpublished PhD dissertation, University of Sydney.

Higham, C. 1998. Noen U-Loke and the implications for the origins of early states. Paper presented at the $16^{\text {th }}$ Congress of the Indo-Pacific Prehistory Association, Melaka, Malaysia, 1-7 July 1998.

- 2011. The Iron Age of the Mun Valley, Thailand. The Antiquaries Journal 91: 1-44. http://doi.org/10.1017/S0003581511000114

- 2012. The Iron Age: synthesis, in C.F.W. Higham \& A. Kijngam (ed.) The origins of the civilization of Angkor. Volume 6. The excavation of Ban Non Wat. Part 4: the Iron Age, summary and conclusions: 331-70. Bangkok: Fine Arts Department.

- 2014. From the Iron Age to Angkor: new light on the origins of a state. Antiquity 88: 822-35. http://doi.org/10.1017/S0003598X00050717

Higham, C. \& T. Higham. 2009. A new chronological framework for prehistoric Southeast Asia, based on a Bayesian model from Ban Non Wat. Antiquity 83: 125-44. http://doi.org/10.1017/S0003598X00098136

Higham, C., A. Kijngam \& S. Talbot (ed.). 2007. The origins of the civilization of Angkor. Volume 2. The excavation of Noen U-Loke and Non Muang Kao. Bangkok: Fine Arts Department.

Higham, C., J. Cameron, N. Chang, C. Castillo, S. Halcrow, D. O’Reilly, F. Petchey \& L. Shewan. 2014. The excavation of Non Ban Jak, northeast Thailand-a report on the first three seasons. Journal of Indo-Pacific Archaeology 34: 1-41. http://doi.org/10.7152/jipa.v34i0.14721

Kealhofer, L. \& D. Penny. 1998. A combined pollen and phytolith record for fourteen thousand years of vegetation change in northeastern Thailand. Review of Palaeobotany and Palynology 103(1-2): 83-93. http://doi.org/10.1016/S0034-6667(98)00029-3

Kummu, M. 2009. Water management in Angkor: human impacts on hydrology and sediment transportation. Journal of Environmental Management 90: 1413-21. http://doi.org/10.1016/j.jenvman.2008.08.007
Malleret, L. 1959. Ouvrages circulaires du Cambodge (circular earthworks in Cambodia). Bulletin de l'École française d'Extrême-Orient LIX(2): 409-49.

Moore, E. 1985. Survey of irregular moated sites in northeast Thailand. Southeast Asian Studies Newsletter 21: 1-2.

O'ReILly, D. 2014. Increasing complexity and the political economy model: a consideration of Iron Age moated sites in Thailand. Anthropological Archaeology 35: 298-309. http://doi.org/10.1016/j.jaa.2014.06.007

O’Reilly, D. \& G. Scotт. 2015. Moated sites of the Iron Age in the Mun River Valley, Thailand: new discoveries using Google Earth. Archaeological Research in Asia 3: 9-18. http://doi.org/10.1016/j.ara.2015.06.001

O'Reilly, D. \& L. Shewan. 2015. A report on the 2011-2012 excavation of Lovea: an Iron Age, moated settlement in Cambodia. Archaeological Research in Asia 1-2: 32-47. http://doi.org/10.1016/j.ara.2015.02.001

Pottier, C. 1999. Carte archéologique de la Région d'Angkor. Zone Sud. Unpublished PhD dissertation, UFR Orient et Monde Arabe, Université Paris III-Sorbonne Nouvelle.

- 2000. Some evidence of an inter-relationship between hydraulic features and rice field patterns at Angkor during ancient times. Journal of Sophia Asian Studies 18: 99-120.

Scott, G. \& D. O’Reilly. 2015. Rainfall and the circular moated sites in north-east Thailand. Antiquity 89: 1125-38. http://doi.org/10.15184/aqy.2015.130

White, J. 1995. Incorporating heterarchy into theory on socio-political development: the case from Southeast Asia, in R. Ehrenreich, C. Crumley \& J. Levy (ed.) Heterarchy and the analysis of complex societies: 101-23. Washington, D.C.: American Anthropological Association.

White, J., D. Penny, L. Kealhofer \& B.K. Maloney. 2004. Vegetation changes from the late Pleistocene through the Holocene from three areas of archaeological significance in Thailand. Quaternary International 113: 111-32. http://doi.org/10.1016/j.quaint.2003.09.001

Received: 27 April 2016; Accepted: 24 June 2016; Revised: 28 June 2016

(C) Antiquity Publications Ltd, 2017 